\title{
Türkiye’de Modern Arap Edebiyatı Alanında Yayımlanan Eserlerin Nicel ve Nitel Analizi
}

\section{Quantitative and Qualitative Analysis of the Published Works of Modern Arabic Literature Areas in Turkey}

\author{
Hasan Harmanc ${ }^{\text {a, * }}$ \\ ${ }^{a}$ Dr. Öğr. Üyesi Hasan Harmancı, Muş Alparslan Üniversitesi, İslami İlimler Fakültesi, Temel İslam Bilimleri Bölümü, Muş/Türkiye. \\ ORCID: 0000-0001-6801-0692
}

\section{MAKALE BİLGİSI}

\section{Makale Geçmişi:}

Başvuru tarihi: 6 Eylül 2019

Düzeltme tarihi: 8 Şubat 2021

Kabul tarihi: 23 Şubat 2021

\section{Anahtar Kelimeler:}

Modern Arap Edebiyatı

Niceliksel Değerlendirme

Bibliyografya
ÖZ

Bu çalışma Cumhuriyet Türkiye'sinde harf inkılabının yapıldığ 1928 ila 2018 yılları arasında yayımlanan Modern Arap Edebiyatı ile ilgili eserlerin genel bir değerlendirmesini içermektedir. Çalışmaya dâhil edilen türler arasında lisansüstü çalışmalar, çeviri ve telif kitaplar ile makaleler yer alırken diğer türdeki eserler bu araştırmada yer almamıştır. Çalışmadaki makaleler araştırmanın içinde verilmiş olan alan ile ilgili otuz altı akademik dergi taranarak, tezler ise İSAM ve YÖK internet siteleri üzerinden tespit edilmiștir. Araştırma sonucunda, Türkiye'de yüz yıla yakın bir sürede Modern Arap Edebiyatı alanında hangi eser ve yazarların daha çok çalışıldığı, hangi isimlere daha çok odaklanılması gerektiği hem teknik hem de tematik anlamda tespit edilecek boşluk ile bu alanda çalışmak isteyen araştırmacılara yol gösterici mahiyette olacağı düşünülmektedir.

\section{A R T I C LE INFO}

\section{Article history:}

Received: September 6, 2019

Received in revised form: February 8, 2021

Accepted: February 23, 2021

\section{Keywords:}

Modern Arabic Literature

Quantitative Assessment

Bibliography

\section{A B S T R A C T}

This study was made in Republican revolution of letters published in Turkey from 1928 to 2018, which includes an overview of the relevant works of modern Arabic literature. Master's and doctoral theses, translation and books and articles, the other types were not included in this study. The articles in the study were determined by scanning thirty-six academic journals related to the field, and the theses were determined on ISAM and YÖK websites. In Modern Arabic Literature a hundred years Turkey which works and authors, which names to greater focus and technique should be both thematic sense, guiding nature is considered to be the researchers who want to work in this field with the space to be deter-mined.

\section{Giriş}

İçinde bulunduğumuz zaman dilimi gelişen teknolojik olanakların bilimsel çalışmaların sayısına da yansıdığı, her geçen gün binlerce akademik çalışmanın yayımlandığı bir çağdır. Böylesi bir zaman diliminde tek bir disiplinde yapılan çalışmaların takibi bile zorlaşmaktadır. Bu durum farklı ilmi alanlara dair yapılacak literatür/bibliyografya türündeki eserlere duyulan ihtiyacı artırmaktadır. Ayrıca "Arapçanın pek çok dilin aksine geniş bir coğrafyada kullanılan zengin bir kültür dili olması" (Işık, 2016, s. 246) Arap Dili ve Edebiyatı alanında yapılan bu tip çalışmalara ayrı bir önem atfetmektedir.

Literatür taramaları, bibliyografya, dizin türündeki çalışmalar sosyal bilimlerin yanı sıra diğer bilim türleri geçmişte olduğu gibi bugün de yol açma görevini devam ettirmektedir. Kadim zamanlarda bir kâşif bir yere ulaşmak istediğinde nasıl bir haritaya ihtiyaç duyduysa, bu tip literatür çalışmaları da ilim/bilim ile iştigal edenler için aynı görevini üstlenmeye devam etmektedir. “Türkiye'de Modern Arap Edebiyatı Alanında Yayımlanan Eserlerin Nicel ve Nitel Analizi” başlıklı bu araştırma ülkemizde uzun yıllardır makale, tez, kitap gibi

*Sorumlu yazar/Corresponding author

e-posta: hasanharmanci@gmail.com 
pek çok akademik eserin verildiği ve günümüzde de bu say1nın ziyadesiyle arttı̆̆ bir disipline 1ş1k tutmak gayesini taşımaktadır.

\section{Yöntem}

\subsection{Araştırmanın Amaç ve Önemi}

$\mathrm{Bu}$ çalışma ülkemizde yayımlanan Modern Arap Edebiyatı ile ilgili eserlerin nicel ve nitel değerlendirmesini içermektedir. Her geçen gün daha çok kitap, tez, makale ve benzeri türün gün yüzüne çıktığı bu alanda yapılan akademik çalışmaların analizi yine bu alanda yapılacak olan araştırmalara önayak olma, bu minvalde bir yol haritası çıkarma amacı ile hazırlanmıştır.

Diğer bir amaç ise her geçen gün daha fazla eserin görüldüğü bu alanda, çok fazla tekrar edilen müellif ve teliflere işaret etmek suretiyle Modern Arap Edebiyatının henüz çalışılmamış bakir dönemlerine, yeni isim ve farklı eserlerine yönlendirme yapmaktır.

\subsection{Araştırmanın Yöntemi}

Bu araştırmaya Türkiye'de Arap Dili ve Edebiyatı, Arapça Öğretmenliği, Arap Dili ve Belagatı, Mütercim - Tercümanlık gibi bölüm ve anabilim dallarınca üretilen akademik eserlerin yanı sıra alan ile alakalı olması kaydıyla diğer bölümlerde yapılan çalışmalar da dâhil edilmiştir. Makale, kitap ve yüksek lisans - doktora düzeyinde hazırlanan çalışmaları niceliksel açıdan incelemekle birlikte verileri değerlendirme hususunda kısmi anlamda niteliksel açıdan da inceleyen bir çalışmadır. 1928-2018 yılları arasındaki belirli bir zaman dilimini kapsaması sebebiyle kesitsel türde bir çalışmadır. Araştırmada elde edilen eserlerin tür ve sayıları, istatistik ve grafikler yardımı ile incelenmiş olup tarihi seyir içindeki değişiklikler yer yer nitel açıdan da incelenmesi sebebiyle karma türde bir çalışma olmuştur. Makale ölçeğinde hazırlanan bu araştırmada alanın kısıtlı olması sebebiyle verilerin tamamı grafik ve tablo olarak gösterilememiş bununla birlikte söz konusu sayısal veriler mümkün mertebe metin içinde verilmeye çalışılmıştır.

\subsection{Araştırmanın Kapsamı ve Sınırlılıkları}

Çalışmaya 1928 - 2018 yılları arasında Türkiye'de Modern Arap Edebiyatı alanında yapılan Türkçe eserlerle sınırlıdır. Çalışmada taramaya esas alınan çalışmalar arasında aşağıda sıralı liste ile verilmiş süreli yayınlarda yer alan makaleler, lisansüstü çalışmalar, inceleme araştırma türü kitaplar ile birlikte Arapçadan Türkçeye çevrilmiş olan roman, hikâye, şiir, tiyatro ve deneme gibi edebi türlerdeki kitaplar bulunmaktadır. Araştırmamızda tespit ettiğimiz eser türlerinden yüksek lisans ve doktora olmak üzere lisansüstü tezler; roman, hikâye, şiir, tiyatro, vb. türdeki edebi eserler ile birlikte süreli yayınlar bir makale boyutunu aştığı için verilememiş ve genel bir değerlendirme yapmakla yetinilmiştir. Bununla birlikte Modern Arap Edebiyatı ile ilgili dergi dosyaları, antolojik eserler ve inceleme - araştırma türü kitaplar sayıca az olmaları sebebiyle alfabetik sirayla verilerek okurun istifadesine sunulmuştur.

Araştırmaya dâhil edilen dergilerin tespitinde birinci olarak, bünyesinde Arap Dili ve Edebiyatı barındıran Edebiyat fakültelerinin dergileri ile alan itibariyle Temel İslam Bilimleri odaklı İlahiyat fakültesi dergileri tercih edilmiştir. Ülkemizde son yillarda hem İlahiyat / İslami İlimler hem de Edebiyat / Sosyal ve Beşeri Bilimler Fakültelerinin sayısı hızlı bir şekilde arttığı için nispeten eski olan yükseköğretim kurumlarının yayınları tercih edilmiştir. Modern Arap Edebiyatı hakkındaki taranmaya dâhil edilen akademik dergilerin alfabetik sıralaması şu şekildedir:

1. Ankara Üniversitesi Dil ve Tarih-Coğrafya Fakültesi Dergisi.

2. Ankara Üniversitesi İlahiyat Fakültesi Dergisi.

3. Atatürk Üniversitesi Edebiyat Fakültesi Dergisi.

4. Atatürk Üniversitesi İlahiyat Fakültesi Dergisi /

Atatürk Üniversitesi İlahiyat Tetkikleri Dergisi.

5. Bingöl Üniversitesi İlahiyat Fakültesi Dergisi.

6. Cumhuriyet Üniversitesi İlahiyat Fakültesi Der-

gisi.

7. Çukurova Üniversitesi İlahiyat Fakültesi Dergisi.

8. Dicle Üniversitesi İlahiyat Fakültesi Dergisi.

9. Dini Araştırmalar.

10. Dinbilimleri Akademik Araştırma Dergisi.

11. Dokuz Eylül Üniversitesi İlahiyat Fakültesi Der-

gisi.

12. Doğu Araştırmaları.

13. Erciyes Üniversitesi İlahiyat Fakültesi Dergisi.

14. Erzurum Kültür Eğitim Vakfi Akademi Dergisi.

15. Frat Üniversitesi İlahiyat Fakültesi Dergisi.

16. Hitit Üniversitesi İlahiyat Fakültesi Dergisi / Gazi

Üniversitesi Çorum İlahiyat Fakültesi Dergisi.

17. Harran Üniversitesi İlahiyat Fakültesi Dergisi.

18. İnönü Üniversitesi İlahiyat Fakültesi Dergisi.

19. İslâmî Araştırmalar.

20. İ̀lâmî İlimler Dergisi.

21. İstanbul Üniversitesi İlahiyat Fakültesi Dergisi /

Darulfünun İlahiyat.

22. Kahramanmaraş Sütçü İmam Üniversitesi İlahiyat Fakültesi Dergisi.

23. Marife Dini Araştırmalar Dergisi.

24. Marmara Üniversitesi İlahiyat Fakültesi Dergisi.

25. Necmettin Erbakan Üniversitesi İlahiyat Fakültesi

Dergisi / Selçuk Üniversitesi İlahiyat Fakültesi Dergisi.

26. Nüsha Şarkiyat Araştırmaları Dergisi.

27. Ondokuz Mayıs Üniversitesi İlahiyat Fakültesi

Dergisi.

28. Recep Tayyip Erdoğan Üniversitesi İlahiyat Fakültesi Dergisi.

29. Sakarya Üniversitesi İlahiyat Fakültesi Dergisi.

30. Selçuk Üniversitesi Edebiyat Fakültesi Dergisi /

Selçuk Üniversitesi Fen - Edebiyat Fakültesi Dergisi.

31. Selçuk Üniversitesi Sosyal Bilimler Enstitüsü Der-

gisi.

32. Süleyman Demirel Üniversitesi İlahiyat Fakültesi

Dergisi.

33. Şarkiyat İlmi Araştırmalar Dergisi.

34. Şarkiyat Mecmuasi.

35. Uludağ Üniversitesi İlahiyat Fakültesi Dergisi.

36. Yüzüncü Yıl Üniversitesi İlahiyat Fakültesi Der-

gisi.

\subsection{Araştırma ile İlgili Literatür}

Yaptığımız araştırmada Modern Arap Edebiyatı alanında yayımlanan tez, makale ve kitapların nicel değerlendirilmesine dair akademik bir çalışma ile karşılaşılmamış olup, zaman zaman yararlandığımız kısmi derecedeki alakalı eserler şu şekildedir: 
Büşra Göktaş'ın Hüseyin Yazıcı danışmanlığında hazırladığı 1990-2008 yılları arası Arapçadan Türkçeye yapılan çevirileri incelediği yüksek lisans çalışması, niceliksel bir çalışmadan ziyade niteliksel bir çalışmadır. Bahsi geçen zaman dilimi içinde çevirisi yapılan edebi eserlerin içeriğine odaklanıldığ1 görülmüştür. Diğer taraftan ilgili yüksek lisans tezinin araştırmada dikkate aldığı süre on dokuz yıl ile sınırlı tutulmuştur. Bu çalışma hem konuyu ele alış biçimi hem de incelemeye tabi tutulan eser türünün kısıtlı olması bakımından çalışmamızdan farklılaşmaktadır. (Göktaş, 2011, s. 4)

Esra Karabacak ile Tahsin Ömer Tahaoğlu'nun birlikte hazırladığı, Arap Dili, Edebiyatı, Kültürü, Sanatı ve Tarihi Üzerine Yapılan Bilimsel Çalışmalar Bibliyografyası I, başlıklı kitabı niteliksel bir değerlendirmeden ziyade bir dizin çalışması olduğu görülmüştür. (Karabacak \& Tahaoğlu, 1993, s. 50) Söz konusu çalışma niceliksel bir çalışma olup internet imkanının olmadığ bir zaman diliminde mektup vasitasıyla akademisyenlerden bilgi toplanarak hazırlandığını dikkate alırsak bu durumun dezavantaja dönüşüp bunun esere yansıdığını rahatça söylenebiliriz.

Ana bilim dalı ölçeğinde yayımlanan bir diğer eser de Ali Cüneyt Eren'in Mürüvvet Açer ile birlikte hazırladığı, Atatürk Üniversitesi Fen - Edebiyat Fakültesi Doğu Dilleri ve Edebiyatları Bölümünde Yapılan Arap Dili ve Edebiyatı ile İlgili Çalışmalar Dizini (1967-2001) başlıklı çalışmadır. Mevzu bahis Ana bilim dalında otuz beş yıllık bir sürede hazırlanan akademik kitaplar, makaleler ve tezler bir dizin halinde hazırlanmıştır. (Eren \& Açer, 2001, s. 3) Bu çalışmada taranan eserler sadece Modern Arap Edebiyatı ile ilgili olmayıp Klasik Arap Edebiyatı, Arap Dili, Arapça Öğretimi ve alan ile ilgili literatür çalışmalara da alan ile ilgili kitapta yer verilmiştir. Makale içeriğinde alıntı yapılmasa da istifade ettiğimiz bu tip eserler "Kaynakça" başlığı altında zikredilmiştir.

Dizin türünde bir diğer çalışma, “Türkiye'de Arap Dili Alanında Yapılan Yüksek Lisans ve Doktora Tezleri (19562002)", başlığını taşıyan bir makaledir. (Uzunoğlu, 2003, ss. 7-8). Elli yıla yakın bir sürede ülkemizde Arap Dili ve Edebiyatı alanında hazırlanan yüksek lisans ve doktora tezleri kısa bir girişten sonra liste halinde verilmektedir. Devam eden yıllarda iki yeni makale ile (Uzunoğlu, 2005, ss. 7-36, 2015, ss. 1-52) söz konusu dizin çalışması güncellenmiştir.

\section{Araştırma Hakkındaki Sayısal Veriler ve Değer- lendirme}

1928'den 2018 yılına kadar Modern Arap Edebiyatına dair eserlerin genel bir değerlendirmesini ihtiva eden çalışmamız esasen daha geniş ölçekli bir araştırmanın parçasını oluşturmaktadır. Bahsi geçen zaman dilimi içinde ülkemizde Klasik Arap Edebiyatı, Arap Dili, Arapça Öğretimi ve bu disiplin ile ilgili literatür araştırmaları başka çalışmaların konusu olacaktır. Bununla birlikte Modern Arap Edebiyatına dair yap1lan çalışmaların saydığımız diğer alt dallar arasında kapsadığı alanı işaret edebilmek için 1 nolu grafik bizlere yardımcı olacaktır:

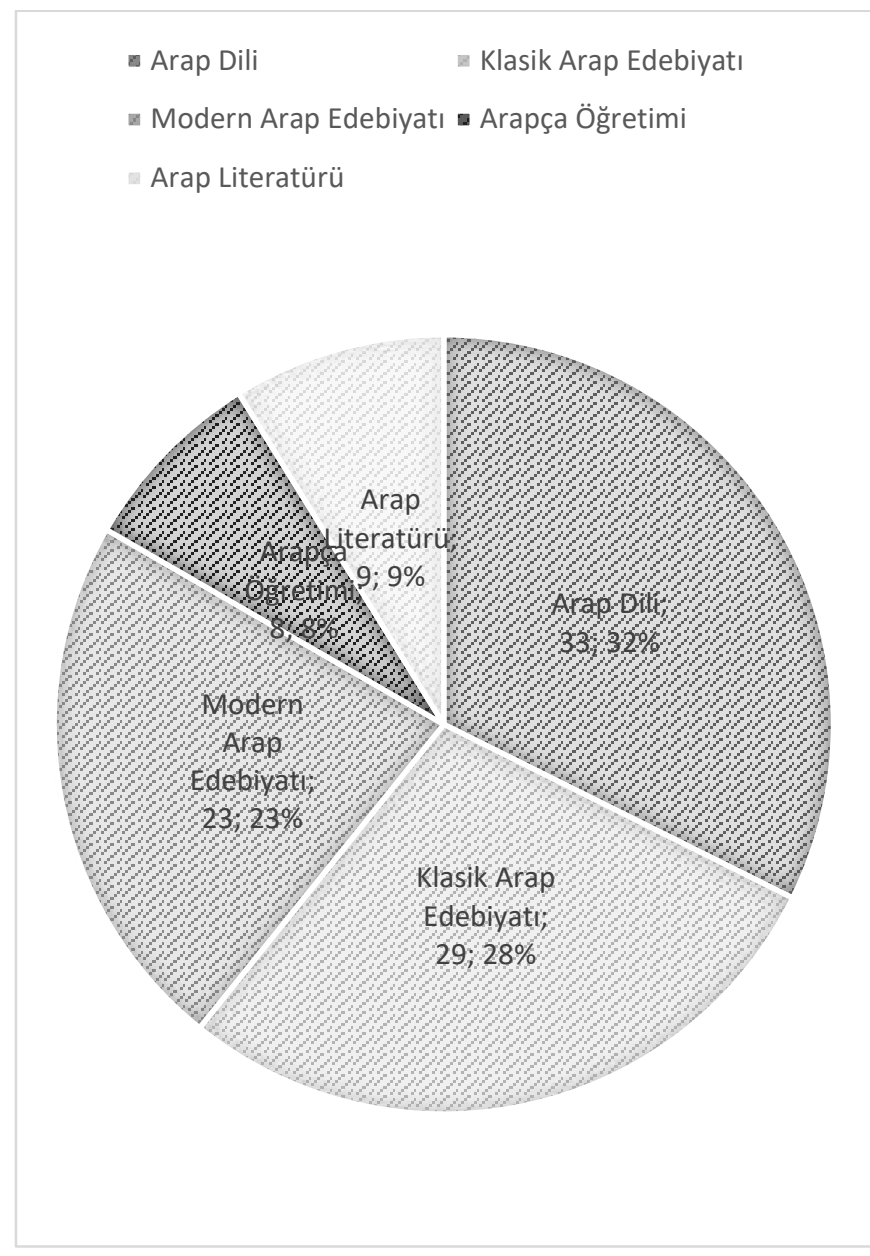

Grafik 1: Arap Dili, Edebiyatı ve Belagatı alanında yapılan çalışmaların birbirlerine oranları

Arap Dili, Edebiyatı ve Belagatı ile ilgili yaptı̆̆ımız literatür taramasında toplamda 3933 eser tespit edilmiş; aynı zamanda disiplinin alt dallarına ve eserlerin türlerine göre de tasnif edilmiştir. 1 nolu grafikte görüldüğü üzere ülkemizde Arapça Dilbilgisi üzerine yapılan çalışmaların sayısı çalışmamızda en çok eserin tespit edildiği alt alan olmuştur. Hemen ardından gelen Klasik Arap Edebiyatı ikinci sıradadır. Araştırmamızın konusu olan Modern Arap Edebiyatına dair üretilen eserlerin sayısı 798 iken diğer alanlara oranı ise \% 23 'tür ve üçüncü sırada yer almaktadır. Hem bu grafiğe hem de modern döneme dair çalışmaların yıl yıl verildiği 3 nolu grafiğe bakıldığında Modern Arap Edebiyatı ile ilgili çalışmaların sayısı yetersiz gibi görünse de sadece edebiyatın değil sosyal bilimlerin temelini oluşturan dile dair çalışmaların ilk sırada yer alması makul karşılanması gereken bir durumdur. Diğer taraftan modern döneme kıyasla çok daha uzun, 1000 yılı aşkın bir süreyi kapsayan Klasik Arap Edebiyatının önemi de yine bu disiplinle iştigal eden her araştırmacının malumudur. Dolayısıyla Türkiye'de Arap Edebiyatının modern dönemine dair yapılan çalışmaların sayı ve oranı tam bu noktada gayet makul görülmektedir. Araştırmamızda alt disiplin olarak Arap Literatürü ve Arapça Öğretimi hakkında diğer bölümlere oranla daha az sayıda çalışma yapıldığı görülmüştür. Mevzu bahis bu iki alt disiplinin oldukça dar bir alanı kapsaması sebebiyle bu sonuç da makul bir durum olarak karşımıza çıkar.

Türkiye'de Arap Dili, Edebiyatı ve Belagatı gibi alanların da dâhil olduğu Şarkiyat merkezli çalışmalar "Darülfünun döneminden bu yana yürütülüyor olsa da, kaliteli çalışmaların 
1950’li y1llardan sonra verildiği”' (Kanar, 2014, s. 1) görülebilir. Şarkiyat alanının tamamına dair yapılan bu tespit, çağdaş edebiyat merkezli olan araştırmamızda da rahatlıkla görülebilir.

Türkiye'de Modern Arap Edebiyatı'na dair yaptığımız bu araştırmada toplam 798 adet eser tespit edilmiştir. Modern Arap Edebiyatı alanında yapılan lisansüstü çalışma sayısı 154 olmuş, bu sayının 102 adedini yüksek lisans tezi, 52 adedini doktora tezi oluşturmuştur. Roman, şiir, hikâye gibi edebi türlerde yapılan tercüme kitapların toplamı 334, inceleme - araştırma türü kitapların sayısı ise toplamda 76 adet olarak belirlenmiştir. Türkiye'de Modern Arap Edebiyatı ile ilgili hazırlanan makalelerin sayısı ise 234'tür.

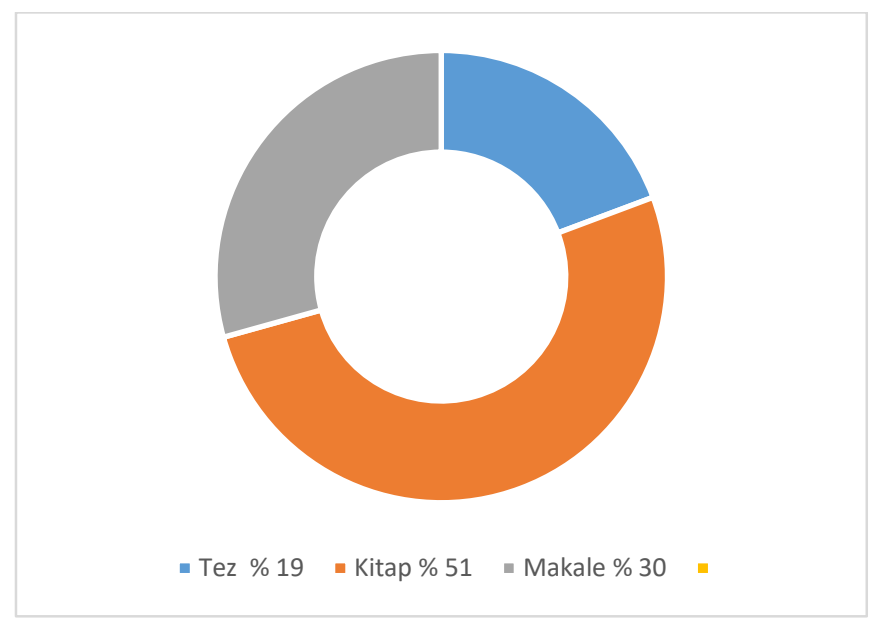

Grafik 2: Modern Arap Edebiyatına Dair Hazırlanan Eserlerin Yüzdeleri

Türkiye'de kitap, makale ve lisansüstü çalışmalar türündeki akademik eserlerin 1980 sonrası dönemde izlediği seyre 3 nolu grafik üzerinden baktığımızda hemen hemen sürekli bir yükseliş çizgisinde olduğu görülmektedir. Ülkemizde ilki 1990'lı yılların ikinci yarısında, diğeri ise 2000'li yılların ikinci yarısında görülen üniversite sayısındaki artışın, bilimsel çalışmalardaki artışa sebep olduğu rahatlıkla söylenebilir. $\mathrm{Bu}$ süreçte sayısal artışa sebep bir diğer etken de şüphesiz Necîb Mahfûz’un 1988 yılında Nobel ödülünü almasıdır. Tüm dünyada olduğu gibi Nobel sonrası süreçte ülkemizde de gözler günbegün artan bir ilgiyle Modern Arap Edebiyatına çevrilmiş ve bu durum akademik çalışmalarda da kendini göstermiştir.

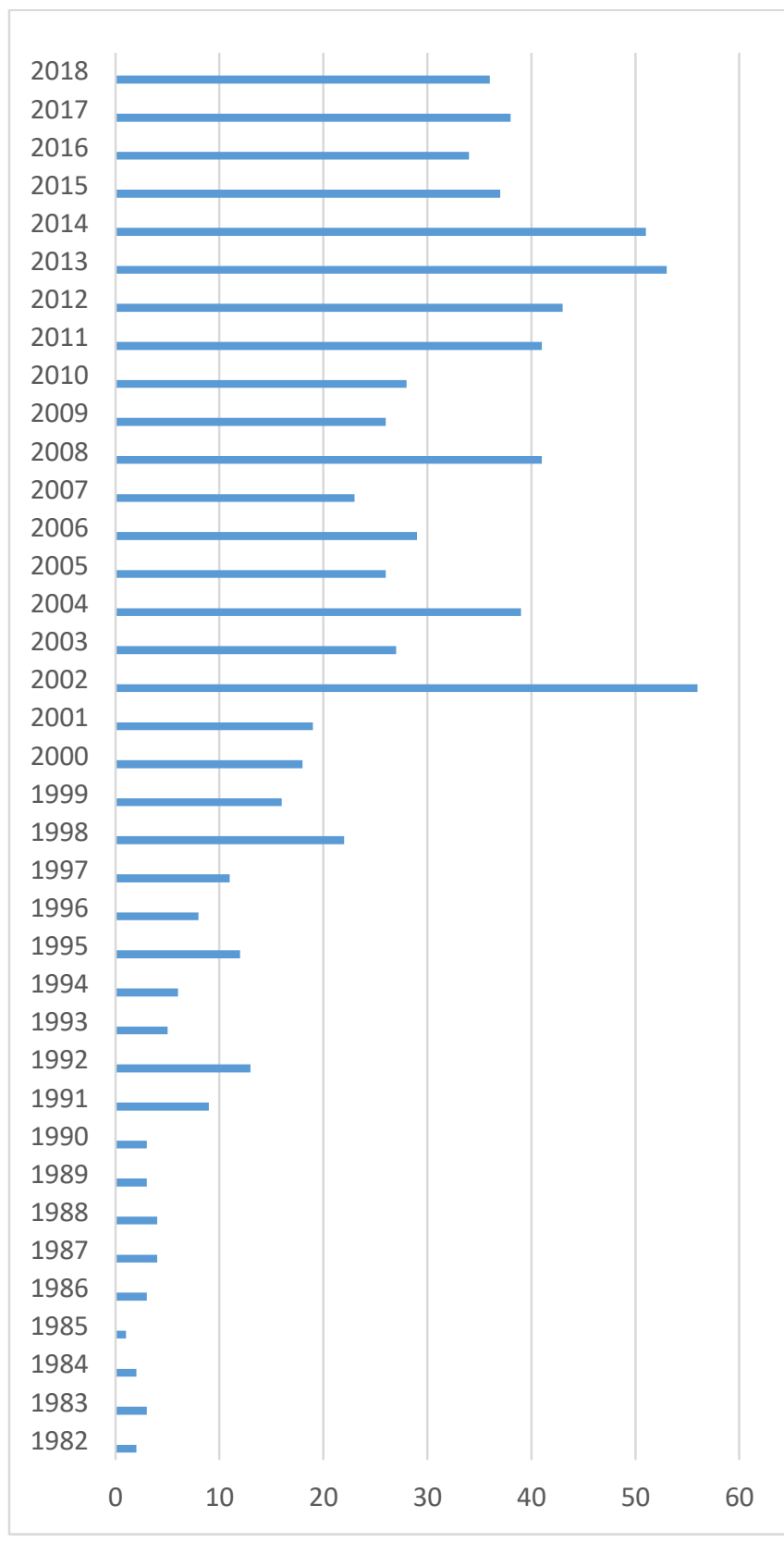

Grafik 3: Modern Arap Edebiyatı çalışmalarının yıllara göre dağılımı (Süreklilik arz etmeyen 1981 ve öncesi çalışmalar bu grafiğe dâhil edilmemiştir.)

Ülkemizde Arap Dili ve Edebiyatı yayın sayısının artması ile ilgili bir diğer önemli etkenin Arap mülteciler olduğu söylenebilir. Özellikle Suriye iç savaşının ardından 2010 sonrası süreçte edebiyat bir tarafa diğer disiplinlerde de kendini göstermiş, yayıncılık dışında kongre, sempozyum ve çalıştay gibi akademik toplantılarda bu önemli konu ele alınmıştır. Bu süreçte Arapçadan Türkçe'ye yapılan Modern Arap Edebiyatı çevirilerinin yanı sıra dilimizden Arapçaya pek çok kitabın tercüme edildiği tespit edilmiştir. Arap Edebiyatı alanındaki artışın bir diğer sebebi ise ana dili Arapça olan mültecilerin Arap Dili ve Edebiyat1, İlahiyat Fakülteleri gibi eğitim kurumlarına ilgi göstermesi olduğu düşünülebilir.

\subsection{Modern Arap Edebiyatı Alanında Hazırlanan Kitaplar}

\subsubsection{Edebi Çeviriler}

Mehmet Kanar, "Ülkemizde Şarkiyatçılığın Özeleştirisi" başlıklı makalesinde öğretim üyeliğine yükseltme kriterlerinde çeviri kitaplara yeterince ehemmiyet gösterilmemesini 
bu alanın büyük bir eksikliği (Kanar, 2014, s. 10) olarak görür. Bu araştırmaya seçilen doksan bir yıllık zaman diliminde Arap Edebiyatının diğer alt dalları ile birlikte Arapçadan Türkçeye yapılan Modern Arap Edebiyatı çevirilerine baktığımızda bu durum açık bir şekilde ortaya çıkar. Zira mevzu bahis kitapların önemli bir kısmının akademi dışından isimler tarafından tercüme edildiği görülmüştür.

Modern Arap Edebiyatından Türkçeye yapılan çevirilere baktığımız zaman ilk dikkat çekici veri, roman türünün -toplamda 170 adetle- çevirisi yapılan diğer edebi türdeki kitapların tamamından sayıca fazla olduğudur.

Klasik dönemde olduğu gibi modern dönemde de önemli bir yer işgal eden şiir, çeviri kitaplar sıralamasında 63 adet ile ikinci sırada yer almaktadır. Ülkemizde olduğu gibi Arap coğrafyasında da kadim zamanlardan itibaren birincil öneme sahip şiir türünün modern zamanlarda kısmen de olsa bu gücünü devam ettirdiği görülmüştür. Harf İnkılabının yapıldığı 1928 yılından günümüze Arapçadan Türkçeye modern dönem eser tercümelerinde şiiri takip eden türler ve sayıları ise şu şekildedir: tiyatro, deneme, anlatı 36; hikâye 29; çocuk edebiyatı 19; anı-hatıra, mektup, günlük, seyahat, biyografi 17 .

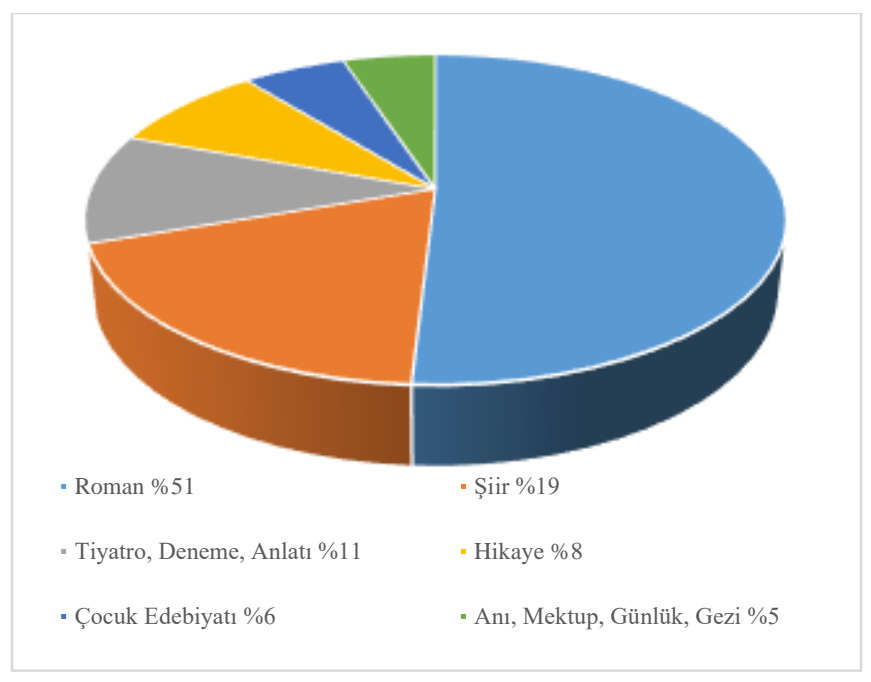

Grafik 4: Arapçadan Türkçeye Yapılan Çevirilerin Oranları

Türk edebiyatında görülen üç türün baskınlığı, Arapçadan Türkçeye yapılan Modern Arap Edebiyatı tercümelerinde de kendini göstermiştir. 2 numaralı grafiğe baktığımız zaman roman, şiir, hikâye gibi edebiyatın bu temel türlerinin yanında mektup, anı, günlük, deneme ve diğerlerinin sayıca oldukça az kaldığı görülmektedir.

Arapçadan dilimize yapılan ilk dönem modern dönem çevirilerinde karşımıza çıkan isimler olarak Halil Cibrân ve Corcî Zeydân'1 görmekteyiz. Henüz hayattayken tüm dünyada büyük bir şöhreti yakalayan şair, yazar ve düşünür Cibrân ülkemizde de Türkçeye tercümesi yapılan ilk çağdaş dönem Arap edebiyatçılarından olmuştur. İlahiyatçı, gazeteci, mütercim kimliği ile tanınan Ömer Rıza Doğrul Cibrân'ın "en-Nebî” kitabını dilimize "Hak Erenler" adıyla tercüme etmiş (Cibran, 1946, s. 92) aynı zamanda esere bir de takdim yazısı yazmıştır. Modern Arap Edebiyatının ilk dönem çevirilerinde karşımıza çıkan bir diğer isim de Corcî
Zeydân'dır. Günümüzde olduğu gibi o zamanın dünyasında da tarihi kurmaca eserler revaçta olmuş ve bu durum Modern Arap Edebiyatından yapılan tercüme eserlerde kendini göstermiştir. Geçtiğimiz yüzyılın başından itibaren pek çok tarihi romanı Osmanlıca olarak da yayımlanan Zeydân'ın Latin harfleriyle karşımıza çıkan ilk romanı Kureyş Bakiresi'dir. Selâmi Münir Yurdatap'ın dilimize tercüme ettiği bu eser Ahmet Saidoğlu Kitabevi tarafindan yayımlanmıştır. (Zeydan, 1944, s. 296). Corcî Zeydân'ın diğer romanları ile birlikte bu romanının tercüme edilmesinde muhteviyat olarak dini içerikli oluşunun önemli bir diğer etken olduğu düşünülebilir.

1980'li yıllarda Modern Arap Edebiyatından tercüme edilmiş 7 edebi eserin üç tanesi dini içerikli diyebileceğimiz şu kitaplardır: Dikenler, Seyyid Kutup, Sancak Yayınları, (Çev. Akif Nuri), İstanbul 1984, 171 ss; Vahşi Dikenler, Sahar Khalifa, Akabe Yayınları, (Çev. İlhan Kaya), İstanbul 1988, 153 ss; Ashabı Kehf - Măgara Arkadaşları, Tevfik el-Hakîm, Kayıhan Yayıncılık, (Çev. Talat Koçyiğit), İstanbul 1980, 128 ss.

Ülkemizde yayınevlerinin dikkatini Modern Arap Edebiyatı'na yönelttiği yıllar 1990'lar olur. Bu zaman diliminde önceki on yıla kıyasla toplam 54 çeviri eserin dilimize kazandırıldığını dolayısıyla sekiz kata yakın bir edebi çevirinin yapıldığını görürüz. Bu artışta mevzu bahis yıllarda daha çok marka ve kitap ile görünen muhafazakâr cenahtan yayıncıların görünür olması önemli etkendir. Ali Ahmed Bakesir, Cihâd er-Recbî ve Necîb el-Kiylanî gibi isimlerin çok say1daki eserinin yayımlanmasıyla kendini gösterir. Bu yıllarda romanı yayımlanan diğer Arap yazarlar arasında başta Necîb Mahfûz ve Amin Maalouf olmak üzere Tevfik el-Hakîm, Tahar Ben Jelloun*, Abdulrezzak Gurnah, Rafik Schami, İhsan Abdülkuddüs, Mihail Nuayme, Yahya Hakkı ile birlikte Tayyip Salih önemli bir yer tutar. Arap feminist yazarlardan Melike Mukaddem, Assia Djebar'ın romanları ilk kez, Neval elSaadavi'nin ise ilki 1987 olmak üzere ikinci kez yine bu yıllarda dilimize kazandırılmıştır. Şiir türünde kitapları çevrilen isimler ise Mahmud Derviş, Nizar Kabbani, Adonis ve Nâzik el-Melâike'dir. Hikâye, tiyatro, deneme, anı, mektup gibi türlerde 1990'lı itibariyle karşımıza çıkan diğer isimler şunlardır: Cihâd er-Recbî, Tevfik el-Hakîm, Nabia Abbott, Taha Hüseyin, Rifa'a Tahtavi.

2000'li yıllar Modern Arap Edebiyatına dair yapılan tercümelerin kat kat arttığı bir zaman dilimidir. 2000 yılından 2009 yılının sonuna kadar çeşitli edebi türlerden yapılan tercüme sayısı 132'dir. Önceki yıllarda kitapları yayımlanan yazar ve şairlere ek olarak Türki el-Hamad, Jamal Mahjoub, Anton Şammas, Diana Abu-Jaber, Yasmina Khadra, Falih Mahdi, Ala el-Asvani, Ghada Karmi, Gamal Gitani, Selva Nuaymi, İbrahim Nasrallah, Şerif Hutate, Yusuf el-Kaid, Raca el-Sana, Etel Adnan, Hanan el-Shaykh, Hulud el Mualla, Muhammed Bennis, Hannân Avvâd, Fatiha Mürşit, Fedvâ Tûkân, Aişe el-Basrî, Ğade es-Semmân, Samir el-Yo-

\footnotetext{
* Araştırmacıların daha kolay istifade etmesi adına bu ve diğer edebiyatçıların isimlerinin çevirmenlerce tercih edilen yazılış şekline müdahale edilmemiştir.
} 
ussef, Yusuf Cevher, Zekeriya Tamir, Selim Berekat, Mourid Barghouti, Yusuf el-Huveyyik, Ahmed Emin, Abdurrahman Şarkavi, Abdurrahman Munîf, Salih el-Kallâb.

2010'dan 2018'e çalışmamıza konu olan alanda yayımlanan eser sayısının, dokuz yıllık bir zaman dilimi taranmasına rağmen toplamda 139 kitapla önceki on yılların en yüksek rakamına ulaştığı tespit edilmiştir. Bu yıllarda Modern Arap Edebiyatı adına bir karakteristik özellik olarak Necib Mahfuz'un ve Amin Maalouf eserlerine giderek büyük bir ilginin olduğudur. Yeni çevirmenlerle yeniden baskılarla birlikte her iki yazarın eserlerinin yeni baskısı ayrıca daha önce yayımlanmamış pek çok yeni kitabı okurla buluşmuştur. Ebu Bekir Hamit Kehhal, Ahdaf Soueif, Safiya Hussain, Mey Ziyade, Ahmed Saadavi, İlyas Huri, Muhammed S. el-Azab gibi isimler roman türünde; Modern Arap Edebiyatında daha önce pek çok defa çevrilen öncü şairlerin yanı sıra Emel Musa, Ahmed eş-Şehavi, Ali Hazmi, Maram al-Masri, Hulud el-Mualla, Ayşe Basri, Eşref Ebu Yezit, Gassan Zaktan gibi isimler de bu türde 2000'lerde ilk kez dilimize çevrilmiştir.

2010 yılından 2018 yılına kadar toplam dokuz yılda, İslam Tarihi, Sahabe hayatı, dini içerikli roman ve diğer edebi eserlerin sayıca yine çok olduğu görülmüştür. Türkiye'de Modern Arap Edebiyatı'nın ilk örneklerinin görüldüğü söz konusu muhteviyattaki eserler 2010 - 2018 yılları arasında da kendini göstermiştir. Corci Zeydan, Abdulhamid Cude esSahhar, Yusuf el-Karadavi, Ali Ahmed Bakesir gibi yazarlar pek çok tekrar ve ilk baskı kitabıyla gün yüzüne çıkmıştır.

2010'lu yıllar Türkiye'de çocuk yayıncılığının büyük sükse yaptığı bir zaman dilimidir ve bu gelişim Arapça'dan Türkçe'ye yapılan Arap çocuk edebiyatı kitaplarında da kendini göstermiştir. Fatıma Şerafeddin, Abir Ballan ve Rafik Schami gibi isimlerden çok sayıda çocuk kitabının dilimize kazandırıldı̆̆ 1 tespit edilmiştir.

\subsubsection{Inceleme Araştırma Kitapları \& Antolojik Kitaplar}

1928'den 2018'e kadar Modern Arap Edebiyatı alanında tespit edilen inceleme araştırma kitap sayısı 48, antolojik kitap sayısı ise 20 olmuştur. İlk örneklerini olması gerektiği gibi daha çok monografik tarzda verilen inceleme türü eserlerde ilerleyen yıllarla birlikte dönemsel, tematik ve çeşitli edebi akımlar üzerine kitaplar görülmeye başlanmıştır. Bu başlık altında inceleyeceğimiz antolojik kitaplar da inceleme araştırma türünden çok daha önce kendini göstermiştir. Antolojik eserlerin mevzu bahis ülke edebiyatına dair en genel bilgi veren bir yapıda olması sebebiyle ilk örnekler olarak karşımıza çıkması da gayet doğaldır. Nitekim araştırmamızda Modern Arap Edebiyatına dair hazırlanan ilk eser 1974 yılında yayımlanmış Filistin şiiri örneklerinden yapılan bir antolojik kitaptır. (Kadir, Timuçin, \& Salom, 1974, s. 95)

Yine bu antoloji türünde karşımıza çıkan geniş bir derleme kitap Nuri Pakdil'in 1976 yılında Edebiyat Dergisi Yayınlarınca yayımlanan Çağdaş Arap Şiiri başlıklı seçkisidir. Önde gelen pek çok Arap ülkesinden eserler seçen Pakdil şiirleri Arapçadan değil Fransızcadan tercüme ettiği görülmüştür ki, bu vakıa Cemal Süreya'nın eleştirisine sebep olmuştur. Şairin çağdaş Arap şiirine Fransızca güldestelerin kaynak olamayacağ1 eleştirisini kabul etmektedir. (Harmanc1, 2015, s. 311) Nuri Pakdil 1998 yılında Arap Siiri antoloji kitabının yine Güldeste başlığıyla ikinci cildini yayımlamıştır. 1980’li yıllarda yine Edebiyat Dergisi Yayınları tarafından yayımlanan Şaban Özdemir'in hazırladığı Çağdaş Arap Öyküsü, diğeri de Azmi Yüksel'in hazırladığ 1 Çağdaş Arap Edebiyatından Seçmeler başlıklı kitaptır. Modern Arap Edebiyatından yapılan edebi eser tercümeleri ve lisanüstü çalışmalardaki artışın 90'lardan itibaren antolojik kitaplarda da çok fazla örnekle karşımıza çıktığ 1 görülmüştür.

Yaptığımız araştırmada ülkemizde Modern Arap Edebiyatı alanında hazırlanan antolojik kitaplardan tespit edilenler şu şekildedir:

Arap ve Fars Kadın Öykücülerden İnciler, Gamze Yücetürk - Serpil Yıldırım, Hece Yayınları, Ankara 2016, 279 ss.

Arap Hikâyesinden Seçmeler, Hüseyin Yazıcı, Çantay Kitabevi, İstanbul 1996, 334 ss.

Arap Şiiri -Güldeste- II, Nuri Pakdil, Edebiyat Dergisi Yayınlar1, Ankara 1998, 271 ss.

Bir Avuç Hurma - Modern Arap Edebiyatı Öykü Seçkisi, (Der. İbrahim Şaban), İstanbul 2018, 80 ss.

Çağdaş Arap Aşk Şiirleri Antolojisi, Metin Fındıkçı, Can Yayınları, İstanbul 2011, 296 ss.

Çağdaş Arap Edebiyatı Seçkisi, Rahmi Er, Kültür ve Turizm Bakanlığı Yayınları, Ankara 2004, 320 ss.

Çağdaş Arap Edebiyatından 33 Şair, Ali Nar, İslami Edebiyat Yayınları, İstanbul 2004, 192 ss.

Çağdaş Arap Edebiyatından Seçme Metinler, Atatürk Üniversitesi, Fen - Edebiyat Fakültesi Yayınları, (Çev. Aysel Ergül - Riza Halilov), Erzurum 2000, 200 ss.

Çăgdaş Arap Edebiyatından Seçmeler, Azmi Yüksel, Ankara Üniversitesi Dil Tarih Coğrafya Fakültesi Yayınları, Ankara 1984, 197 ss

Çağdaş Arap Şiiri -Güldeste-, Nuri Pakdil, Edebiyat Dergisi Yayınları, Ankara 1976, 344 ss.

Çağdaş Arap Hikâyelerinden Seçmeler Onuncu Günde Kaplanlar, Erdinç Doğru, Meneviş Yayınları, İstanbul 2002, 232 ss.

Çağdaş Arap Hikâyesinden Seçmeler, Ali Nar, Elif Yayınlar1, İstanbul 2005, 183 ss.

Çağdaş Arap Kadın Şairler Antolojisi, Metin Fındıkçı, Hayal Yayınlar1, İstanbul 2010, 104 ss.

Çağdaş Arap Kadın Şairler Antolojisi, Metin Fındıkçı, Kaos Çocuk Park1, İstanbul 2018, 330 ss.

Çağdaş Arap Öyküleri, Hüseyin Yazıcı, Kaknüs Yayınları, İstanbul 1999, $256 \mathrm{ss}$.

Çağdaş Arap Öyküsü, Şaban Özdemir, Edebiyat Dergisi Yayınları, Ankara 1982, 189 ss.

Çağdaş Arap Şiirleri Antolojisi, Metin Fındıkçı, Can Yayınla-r1, İstanbul 2011, 296 ss.

Çağdaş Libya Edebiyatı Şiir Seçkisi, Nurettin Ceviz, Aktif Yayınevi, Ankara 2005, 169 ss.

Filistin Şiiri, A. Kadir - Afşar Timuçin, Yazko, İstanbul 1974, 95 ss.

Modern Suriye Edebiyatı Öykü Seçkisi, Ömer İshakoğlu, Demavend Yayınları, İstanbul 2015, 138 ss. 
Modern Arap Edebiyatı ile ilgili inceleme - araștırma türündeki eserlere geri dönecek olursak karşımıza çıkan ilk kitaplardan birisi 1981 yılında Bedrettin Çetiner tarafından monografik tarzda hazırlanan, Taha Hüseyin, Hayatı Eserleri ve XX. Yüzyıl Arap Edebiyatındaki Yeri, başlıklı çalışmasıdır. $\mathrm{Bu}$ çalışmayı dönemsel bir çalışma olan Ahmet Savran'ın, 19. yy. Osmanlı Döneminde Yeni Arap Edebiyatı başlıklı çalışması takip eder. Türkiye'de Modern Arap Edebiyatı alanında pek çok eser verip pek çok öğrenci yetiştirmiş Erol Ayyıldız Mustafa Lütfi el-Menfeluti ve Mahmud Taymur hakkındaki iki eser ile inceleme araştırma türündeki kitapların erken örneğini vermiş bir isimdir. Bedrettin Aytaç tarafından çevrilen Jacob M. Landau'nun Modern Arap Edebiyatı Tarihi, başlıklı kitabı bu türün nadir tercümelerinden biridir.

Dini içerikli edebi eserlerin bir yansıması olarak Ali Nar'ın Necib el-Kîlanî'den çevirdiği, İslami Edebiyata giriş kitabı karşımıza çıkan ilk örneklerdendir. Bu minvalde bir başka örnek İbrahim Sarmış'ın hazırladığı, Bir Edebiyatçı Olarak Seyyid Kutup başlıklı çalışmasının yayın yılı ise 1993'tür. Devam eden yıllarda hem ülke edebiyatları, hem de dönemsel incelemelerde hacimli eserler verilmekle birlikte Modern Arap Edebiyatı alanında daha çok bir isim veya bir eser üzerinden yapılan incelemeler ağırlığı oluşturmaktadır. 1928 2018 yılları itibariyle Türkiye'de Modern Arap Edebiyatı konulu inceleme araştırma türünde hazırlanan kitaplar şu şekildedir:

19. yy. Osmanlı Döneminde Yeni Arap Edebiyat1, Ahmet Savran, Atatürk Üniversitesi Fen Edebiyat Fakültesi Yayınlar1, Erzurum 1991, 195 ss.

1868-1932 Mısır'da Bir Türk Şair Ahmet Şevki, Ahmet Kazım Ürün, Kaknüs Yayınları, İstanbul 2002, 176 ss.

Abdurrahmân eş-Şarkâvi'nin Romanlarında Toplumsal Eleştiri, Asiye Çelenlioğlu, Lambert Academic, İstanbul 2017, 304 ss.

Abdüsselam el-Uceylî’nin Edebi Kişiliği ve Hikâyeciliği, Dursun Hazer, Araştırma Yayınları, Ankara 2004, 224 ss.

Ahmet Hasan Zeyyat ve Arap Edebiyatındaki Yeri, Cemal Abdullah Aydın, Kitabi Yayınevi, İstanbul 2018, 238 ss.

Ali Ahmed Bakesir ve Kabul Edilen Dua, Sait Uylaş, Atatürk Üniversitesi Fen - Edebiyat Fakültesi Yayınları, Erzurum 2002, 61 ss.

Amerika'daki Arap Göç Edebiyatında Din Anlayışı, Sultan Şimşek, Yalın Yayıncılık, İstanbul 2012, 358 ss.

Arap Edebiyatında Kisa Hikaye, Nurettin Turgay, Tibyan Yayıncılık, Diyarbakır 2015, 162 ss.

Arap Romanında Türkler, Şükran Fazlıoğlu, Küre Yayınları, İstanbul 2006, 316 ss.

Arap Ülkeleri Sosyo-Kültürel Yapısı, Ahmet Kazım Ürün, Çizgi Kitabevi Yayınları, Konya 2016, 168 ss.

Arap Ülkelerinde Çocuk Edebiyatı Kaynakları Doğuşu ve Gelişimi, Yusuf Köşeli, Türkiye Alim Yayınları, İstanbul 2014, 267 ss.

Bir Edebiyatçı Olarak Seyyid Kutup, İbrahim Sarmış, Fecr Yayınevi, Ankara 1993, 254 ss.
Cibran Halil Cibran'ın Ölümünün 80. Yıldönümü Münasebetiyle Doğu Edebiyatlarında Göç Olgusu, Der. İbrahim Şaban - Eyüp Sarıtaş, Akademi Titiz Yayınları, İstanbul 2012, 178 ss.

Çağdaş Arap Kadın Anlatılarında Kadının Kimlik Arayışı, Yusuf Köşeli, Gece Kitaplığı, Ankara 2016, 356 ss.

Çăgdaş Arap Edebiyatçısı Zekeriya Tamir Edebi Kişiliği ve Hikâyeciliği, Ahmet Bostancı, Nun Yayıncılı, İstanbul 2007, 302 ss.

Doğu Edebiyatında Kadın, Kollektif, Demavend Yayınları, İstanbul 2016, 224 ss.

Emir Şekip Arslan (İlmi ve Edebi Şahsiyeti), Ömer İshakoğlu, Demavend Yayınları, İstanbul 2015, 133 ss.

Filistin ve İki Şair Emel Dunkul - Mahmud Derviş, Faruk Bozgöz, Araştırma Yayınları, Ankara 2004, 158 ss.

Filistinli Şair Mahmud Derviş - Hayatı, Edebi Kişiliği, Eserleri, Nurullah Yılmaz, Fenomen Yayınları, Erzurum 2013, 376 ss.

Göç Edebiyatı, Hüseyin Yazıcı, Kaknüs Yayınları, İstanbul 2002, 608 ss.

Halîm Berekât ve Altı Gün Adlı Romanı, İlknur Emekli, Fenomen Yayıncılık, Erzurum 2017, 159 ss.

Hazırlayıcı Faktörleri Işı̆̆ında Modern Arap Edebiyatına Giriş, Mehmet Emin Yalar, Emin Yayınları, Bursa 2009, 200 ss.

İki Kadın Bir Feminizm, Senem Soyer, Net Kitaplık Yayınc1lik, İstanbul 2017, 312 ss.

İslami Edebiyata Giriş, Necib el-Kîlanî, Risale Yayınları, (Çev. Ali Nar), İstanbul 1988, 157 ss.

İslami Edebiyatta Dua, Abdülhadi Timurtaş, Çıra Yayınları, İstanbul 2018, 247 ss.

Kuşatma Altında Beyrut Günlüğü: Çağdaş Arap Şiirinde Beyrut İşgali, Kemal Kahraman, Beyan Yayınları, İstanbul 2007, 127 ss.

Libya'nın Vatan Şairi: Ahmed Refîk el-Mehdevî (18981961), Hayatı ve Edebî Kişiliği, Nurettin Ceviz, Aktif Yay1nevi, Ankara 2005, 162 ss.

Mahmud Taymur'un Hikâyelerinde Sürükleyici Unsuru ve Sürprizli Sonlar, Erol Ayyıldız, Fatih Yayınevi, Bursa 1992, [?] ss.

Mahmûd Teymûr ve Bilinmeyenin Çağrısı Adlı Romanı, İlknur Emekli, Fenomen Yayıncılık, Erzurum 2017, 101 ss.

Mısır Romanının Doğuşu ve Muhammed Hüseyin Heykel'in Zeyneb Romanının Tetkiki ve Tahlili, Erol Ayyıldız, Fatih Yayınevi, Bursa 1992, [?] ss.

Modern Arap Edebiyatı Tarihi, Jacob M. Landau, Kültür Bakanlığı Yayınları, (Çev. Bedrettin Aytaç), Ankara 2002, 128 ss.

Modern Arap Edebiyat1, Ahmet Kazım Ürün, Çizgi Kitabevi Yayınları, Konya 2015, 205 ss.

Modern Arap Edebiyatının Usta Kalemleri, Aida İmanquliyeva, IQ Kültür Sanat Yayıncılık, İstanbul 2007, 380 ss. 
Modern Arap Şiiri, Mehmet Yalar, Arasta Yayınları, Bursa 2003, 234 ss.

Modern Arap Şiirinde Yeni Bir Eğilim Kasidetu'n-Nesr, Nurullah Y1lmaz, Fenomen Yayınc1lık, Erzurum 2017, 201 ss.

Modern Libya Edebiyatı Şiir - Öykü, Nurettin Ceviz, Aktif Yayınevi, Ankara 2005, 470 ss.

Modern Misır Romanı - I, Rahmi Er, Hece Yayınları, Ankara 2015, 312 ss.

Modern Mısır Tiyatrosu ve Tevfik el-Hakîm, İsmail Güler, Bursa 2004, [?] ss.

Modern Suriye Hikâyesinin Konuları 1946-1967, Mevlüt Kula, Çizgi Kitabevi Yayınları, Konya 2017, 141 ss.

Mustafa Lütfi el-Menfeluti'nin Paul ve Virginie Tercümesi Üzerine Değerlendirme, Erol Ayyıldız, Fatih Yayınevi, Bursa, 1992, [?] ss.

Necip Mahfuz ve Toplumsal Gerçekçi Romanları, Ahmet Kazım Ürün, Çizgi Kitabevi Yayınları, Konya 2002, 388 ss.

Sadallah Vennûs ve Tiyatroları, Aysel Ergül Keskin, Fenomen Yayıncılık, Erzurum 2011, 192 ss.

Suriye Tarihi, Osmanlı Dönemi Suriyesi'nde Edebi ve Kültürel Hayat, Ömer İshakoğlu, Kabalcı Yayınları, İstanbul 2012, 422 ss.

Şeytanın Biyografisi, Mehmet Yalar, Emin Yayınları, Bursa 2009, 223 ss.

Şiir Çeviri Eleştirisi, Gürkan Dağbaşı, Akdem Yayınları, İstanbul 2018, 178 ss.

Şiirin Galip Aşkın Devrik Kralı / Nizar Kabbanı̂’de Aşk ve Kadın, Aysel Ergül Keskin, Araştırma Yayınları, Ankara 2006, 382 ss.

Taha Hüseyin, Hayatı Eserleri ve XX. Yüzyıl Arap Edebiyatındaki Yeri, Bedreddin Çetiner, İstanbul 1981, 233 ss.

Ülfet el-İdlibi Hikâyelerinde Eski Şam Muhiti ve Kadın, Haz. Dursun Hazer, Emin Yayınları, Bursa 2010, 167 ss.

\subsection{3. Çevirmenler}

Bu alanda Metin Fındıkçı toplamda 37 adet kitap ile en çok çeviri yapan tercüman olarak karşımıza çıkmıştır. Bu eserlerin ikisi dışında kalanların tamamı şiir türündedir. Kitaplarını çevirdiği şairlerden ilk başta Mahmud Derviş ve Adonis'in yanı sira Hulud el-Mualla, Nizar Kabbani, Muhammed Bennis, Emel Musa gibi pek çok isim bulunmaktadır. Metin Fındıkçı Arapça şiir tercümesi denilince akla gelen ilk isimlerden biri olmakla birlikte yaptığı bariz çeviri yanlışlıkları ile de akademik çalışmalarda da ismi geçmektedir. Bu alanda buna bir örnek Şerafettin Yıldız'ın, mütercimin Katkat Yasemin adlı şiir çevirisi hakkında yazdığı eleştirel makalesidir. (Yıldız, 2015, s. 180) Ayrıca Gürkan Dağbaşı Türkiye'de Arap şiir çevirisi üzerine hazırladığı doktora çalışmasında hem Fındıkçı'nın hem de Yıldız'ın yaptığı tercümeyi mukayese ederek incelemiştir. (Dağbaşı, 2017, ss. 6876)

Son yıllarda Arapçadan Türkçeye artarda pek çok çeviri kazandıran Mehmet Hakkı Suçin toplamda 10 kitap, İbrahim Demirci ise 9 kitap yayımlamıştır. Her iki çevirmen için tercüme yaptıkları türün ağırlıklı olarak şiir olduğu görülmüştür. Türkiye'de Mihail Nuayme çevirilerinde karşımıza çıkan isimler Kenan Demirayak ve Hüseyin Yazıcı; başka pek çok farklı mütercim tarafından tercüme edilmekle birlikte Cahit Koytak ise Halil Cibran çevirileri ile son dönemde ön plana çıkmaktadır.

Önce batı dünyasında sonra tüm dünyada büyük bir şöhrete kavuşan Amin Maalouf'un ülkemizde de kitapları en çok satılan yazar olduğu görülmüştür. Esin Talu Çelikkan, Samih Rıfat, Aysel Bora, Sevim Raşa gibi isimleri daha çok Yapı Kredi Yayınları tarafından basılan Maalouf kitaplarının çevirmenleridir. Işıl Alatlı Necib Mahfuz; Işık Ergüden, Tahar Ben Jelloun ve Gamal Gitani; Avi Pardo Ala el-Asvani'nin romanlarında sıklıkla karşımıza çıkan mütercimlerdendir. $\mathrm{Bu}$ kısımda ismi geçen mütercimlerin mevzu bahis kitapları Arapça dışındaki batı dillerinden tercüme ettikleri görülmüştür.

Yukarıda bahsettiğimiz üzere Modern Arap Edebiyatından Türkçeye yapılan tercümelerde önemli bir yekûnu de İslam Tarihi ve dini içerikli romanlar oluşturmaktadır. Abdülhamid Cude es-Sahhâr'ın pek çok romanını Âdem Yerinde, Necib el-Kiylani'nin ise Ali Nar dilimize tercüme etmiştir. Dini içerikli roman olmakla birlikte farklı yazarlardan pek çok kitabı Muharrem Tan, Türkçe'ye kazandırmıştır. Hem kıta Avrupası hem de Amerika Birleşik Devletleri tarafindan kendi dünya görüşlerine uygun olan kitapların öne çıkarılıp tercüme edildiği göz önüne alındığında, dini içerikli Arapça eserlerin de ülkemizde dilimize kazandırılması eğilimi kolay bir şekilde tahmin edilebilir.

Son yıllarda daha çok eserin Türkçe'ye kazandırıldığı Arap çocuk edebiyatı alanında mütercim olarak öne çıkan isimler şu şekildedir: İbrahim Demirci, Mehmet Ali Kayabağlar, Ebubekir Sıddık, Sadık Tanrıkulu, Sevil Tanrıkulu, Ayşe D. Taşkent, Abdülkadir Lale.

\subsubsection{Yayıncilar}

Dünya edebiyatından pek çok eseri dilimize kazandıran Yapı Kredi Yayınları, toplamda 34 kitapla Modern Arap Edebiyatı'ndan da en çok çeviri kitabı yayımlayan yayınevi olmuştur. Bu sayının önemli bir kısmını Amin Maalouf'un eserleri oluşturmaktadır. Türkiye'de yayıncılık dendiğinde ilk akla gelen yayınevlerinden bir diğeri olan Can Yayınlarının bu alandaki çeviri eser sayısı 16, Kırmızı Kedi Yayınlarının 13, Kırmızı Yayınlarının ise 10 adet olarak tespit edilmiştir ki bu üç yayınevinde tercih edilen tercüme dili büyük oranda İngilizcedir.

Çeviri dili olarak Arapçayı tercih eden yayınevlerinden Kaknüs Yayınlarının toplam 14 kitap yayımladığı görülmüştür. Mihail Nuayme ve Halil Cibran'dan yapılan dörder kitap çevirisi önemli yekûnu oluşturmuştur. Yukarıda bahsettiğimiz üzere tüm dünyada daha hayattayken meşhur olan Halil Cibran ülkemizde de okur ve yayıncılar tarafından ilgi görmüş bunun bir yansıması olarak 80'li yılların sonundan itibaren Anahtar Kitaplar Yayınevi, günümüzde de Kapı Yayınları şairin eserlerinin büyük bir kısmını basmıştır. Artshop Yayınlarının yayımladığı kitapların çevirmeni Metin Fındıkçı olarak karşımıza çıkmaktadır. Nar Yayınları yayımladığı çeviri kitapların tamamı çocuk edebiyatı alanındadır. Hece, Everest, Kabalc1, Elif, Demavend, Hit Kitap Modern Arap Edebiyatı alanında karşımıza çıkan diğer yayıncılardır.

Ülkemizde Modern Arap Edebiyatı'ndan kitaplar yayımlayan yayınevlerinde tercih edilen çeviri dilinin ait oldukları düşünsel fraksiyona göre değiştiği de görülmektedir. Sağ 
olarak nitelendirilen yayınevleri orijinal dil Arapçayı tercih ederken, sol yayınevlerinin eserleri çoğunlukla batı dillerinden yaptırdığ 1 görülmektedir. Bir eserin tercümesinin orijinal dil üzerinden yapılması kadar bilimsel bir durum söz konusu değildir. Bununla birlikte ülkemizde Arapça eserlerinin İngilizceden çevrilme ısrarının üzerinde düşünülmesi gereken bir vakıa olduğu söylenebilir.

\subsection{Modern Arap Edebiyatı Alanında Hazırlanan Ma- kaleler}

Ülkemizde araştırmamıza konu olan Modern Arap Edebiyatına dair makalelerin yer aldığı akademik süreli yayınlara baktığımızda Edebiyat ve İlahiyat başta olmak üzere pek çok fakülte neşriyatı karşımıza çıkmakla birlikte bu minvalde başı çeken dergilerin şarkiyat merkezli dergiler olduğunu söyleyebiliriz. Bu noktada Şarkiyat Mecmuası, Nüsha Şarkiyat Araştırmaları, Doğu Dilleri, Doğu Araştırmaları ile birlikte yaşça daha genç olan Şarkiyat İlmi Araştırmalar ve Doğu Esintileri dergileri karşımıza çıkmaktadır.

Yirmi yıla yakın bir süredir istikrarlı yayın politikası ile şarkiyat denince ilk akla gelen dergilerinden biri olan Nüsha'nın (Ceviz, 2002, s. 235) Modern Arap Edebiyatına sayfalarında en fazla yer ayıran dergi olduğu görülmektedir. Aralık 2020 itibariyle 50. sayıya ulaşan dergi, araştırma konumuz ile ilgili 73 adet makale ihtiva etmekte olup akademik süreli yayınlar arasında ilk sırada yer almıştır. Doğu dillerinin ilk akademik dergisi unvanını taşıyan ve birinci sayısını 1956 yılında çıkaran Şarkiyat Mecmuası'nın yayın periyodunda zaman zaman fasılalar olsa da (Yazıc1, 2002, s. 8) alan ile ilgili pek çok akademik çalışmanın yer aldığı görülmüştür. Nihayetinde 36 makale ile Modern Arap Edebiyatı konulu en çok makalenin yer aldığı ikinci dergi olmuştur. Yirmi küsur yıldır sık bir periyotla yayın hayatına devam eden EKEV Akademi Dergisi'nde araştırma konumuzla ilgili 25, Ankara Dil Tarih Coğrafya Fakültesi dergisinde ise 12 makale tespit edilmiştir.

Yaptığımız araştırmada Modern Arap Edebiyatı konulu makaleler ağırlıklı olarak edebiyat fakültelerinin doğu dilleri bölümlerinden çıksa da, Uludağ Üniversitesi İlahiyat Fakültesi ögrretim üyesi Prof. Dr. Erol Ayyıldız ve ardından Prof. Dr. Mehmet Yalar'ın yayımladığı eserler ve yönettiği tezlerin fakülte dergisine yansıdığı görülmüş Uludağ Üniversitesi İlahiyat Fakültesi Dergisinde 9 adet makale yer almıştır. Araştırmamızda Modern Arap Edebiyatının dergiler ve bu alanla ilgili makale sayıları şu şekildedir:

Doğu Araştırmaları 8, Selçuk Üniversitesi Edebiyat Fakültesi Dergisi 7, Süleyman Demirel Üniversitesi İlahiyat Fakültesi Dergisi 7, Atatürk Üniversitesi İlahiyat Fakültesi Dergisi 6, Atatürk Üniversitesi Edebiyat Fakültesi Dergisi 6, Doğu Dilleri Dergisi 5, Marife 5, Yüzüncü Yıl Üniversitesi İlahiyat Fakültesi Dergisi 3, Selçuk Üniversitesi Sosyal Bilimler Enstitüsü Dergisi 3, Dokuz Eylül Üniversitesi İlahiyat Fakültesi Dergisi 3, Recep Tayyip Erdoğan Üniversitesi İlahiyat Fakültesi Dergisi 3, Sakarya Üniversitesi İlahiyat Fakültesi Dergisi 2, İstanbul Üniversitesi İlahiyat Fakültesi Dergisi 2, Dicle Üniversitesi İlahiyat Fakültesi Dergisi 2, Kahramanmaraş Sütçü İmam Üniversitesi İlahiyat Fakültesi Dergisi 2, Dinbilimleri Akademik Araştırma Dergisi 1, Dini Araştırmalar 1, Erciyes Üniversitesi İlahiyat Fakültesi Dergisi 1, On Dokuz Mayıs Üniversitesi İlahiyat Fakültesi Dergisi 1, Bingöl Üniversitesi İlahiyat Fakültesi Dergisi 1, Çu- kurova Üniversitesi İlahiyat Fakültesi Dergisi 1, Fırat Üniversitesi İlahiyat Fakültesi Dergisi 1, Hitit Üniversitesi İlahiyat Fakültesi Dergisi 1, Selçuk Üniversitesi İlahiyat Fakültesi Dergisi / Necmettin Erbakan Üniversitesi İlahiyat Fakültesi Dergisi 1, Şarkiyat İlmi Araştırmalar Dergisi 1, Marmara Üniversitesi İlahiyat Fakültesi Dergisi 1. Diğer taraftan Cumhuriyet Üniversitesi İlahiyat Fakültesi Dergisi, Ankara Üniversitesi İlahiyat Fakültesi Dergisi, Harran Üniversitesi İlahiyat Fakültesi Dergisi, İnönü Üniversitesi İlahiyat Fakültesi Dergisi, İslami Araştırmalar Dergisi ve son olarak İslâmî İlimler Dergilerinde ise söz konusu yıllar arasında Modern Arap Edebiyatı ile ilgili makaleye rastlanmamıştır.

Türkiye'de süreli yayınlarda dünya edebiyatına büyük bir önem vermiş olan Edebiyat Dergisi sayfalarında Arap Edebiyatına, hassaten modern Arap şiirine yer açmıştır. 1970'li yıllardan itibaren Mahmut Derviş, Nizar Kabbani, Tevfik elHakîm, Ahmed Şevki gibi öncü isimlerin eserlerinden tercümeler (Harmanc1, 2015, s. 344) bu dergide kendine yer bulmuştur.

Türkiye'de akademik olmayan dergilerden Modern Arap Edebiyatı hakkında en çok yayın yapmış, sayfalarını bu edebiyata ayırmış bir diğer süreli yayın da hiç kuşkusuz Hece Öykü dergisidir. Hikâye türünde yakın coğrafyamızda yer alan hemen her Arap ülkesinin öykücülüğü hakkında kuramsal ve çeviri örnekleriyle sayfalarında yer ayırmıştır. Akademik olmayan süreli yayınlarda Modern Arap Edebiyatını gündemine taşıyıp dosya konusu yapan dergilerin listesi ise şu şekildedir:

“Arap Yazarlarıyla Önemli Buluşma”, Edebiyat ve Eleştiri, Say1: 75, Ankara 2004.

“Çağdaş Cezayir Öyküsü”, Hece Öykü, Sayı: 35, Ankara 2009.

"Çağdaş Filistin Öyküsü”, Hece Öykü, Sayı: 25, Ankara 2008.

“Çağdaş Filistin Şiiri”, Hece, Sayı: 136, Ankara 2008.

“Çağdaş Mısır Öyküsü”, Hece Öykü, Sayı: 31, Ankara 2009.

“Çağdaş Suriye Öyküsü”, Hece Öykü, Sayı: 27, Ankara 2008.

"Doğu Edebiyatları Özel Sayısı", Folklor / Edebiyat, Sayı: 58, Ankara 2008.

"Filistin - İşgal Altındaki Topraklarda Kültür ve Sanat”, Milliyet Sanat Dergisi, Sayı: 14, İstanbul 1988.

\subsection{Modern Arap Edebiyatı Alanında Hazırlanan Tez-} ler

Türkiye'de Modern Arap Edebiyatı alanında hazırlanan lisansüstü çalışmalarının ilk örneklerine baktığımızda bunların daha çok hayatı, eserleri ve edebi kişiliği şeklinde genel bir çerçevede çalışıldığını görürüz. Mevzu bahis alanda herhangi bir çalışmanın yapılmadığı bir zaman dilimini dikkate aldığımızda eserlerin monografik olması doğaldır. Sonuç olarak Modern Arap Edebiyatı ile ilgili bu ilk dönem lisanüstü tezleri takip eden akademik araştırmalar olması gerektiği gibi daha spesifik şekilde konuyu daha derin bir şekilde ele alan çalışmalara dönüşmüştür. 
Alanla ilgili söz konusu çalışmalara Erol Ayyıldız’ın Nihâd Mazlum Çetin yönetiminde hazırladığ " 20 . Asır Arap Edebiyatında Mustafa Sâdık er-Râfi'î'nin Yeri”, 1978 tarihli çalışması buna örnek verilebilir. Bu minvalde bahsedebileceğimiz 1983 yilında kabul edilmiş iki tezden ilki Halit Zevalsiz'in “Abbas Mahmud Akkâd, Hayatı, Eserleri ve XX. Yüzyıl Arap Edebiyatındaki Yeri” başlıklı çalışması ile Osman Aşçıoğlu'nun hazırladığı "Mustafa Lütfî Menfelûtî, Hayatı, Eserleri, XIX. ve XX. Asır Arap Edebiyatındaki Yeri” başlıklı çalışmasıdır. 1981 yılında yayımlanan Bedrettin Çetiner imzal1 "Tâhâ Hüseyin, Hayatı, Eserleri ve XX. Yüzyıl Arap Edebiyatındaki Yeri” başlıklı araştırma yine dikkat çekici bir başka eserdir.

1980’li yıllarda araştırma başlığımızla ilgili oldukça az sayıda lisansüstü çalışma yapılmışken 90'lı yıllardan itibaren bir hareketlenme karşımıza çıkar. Söz konusu pozitif yönlü değişimde Necîb Mahfûz'un aldığı Nobel Edebiyat ödülü akla gelecek ilk etkidir. Fakat bunun yanı sıra Sovyetler Birliği'nin dağılması, internet ve gelişen iletişim olanakları vasıtası ile dünyanın global bir köy haline gelmesi dolayısıyla toplumların eskisi gibi içe kapanık olarak yaşamaması bu alana ilgideki söz konusu hareketlenmenin sebebi olarak düşünülebilir.

Modern Arap Edebiyatı alanında hazırlanan lisansüstü çalışmalardaki pozitif yönlü değişim ilk kez 1992 yılında kendini göstermiş ve önceki yılların aksine 5 adet tez üretilmiştir. Bu yılı takip eden yıllardan 1995 'te de yine 5 adet lisansüstü çalışma tespit edilmiştir. Yaptığımız araştırmada 1997 yılında 4, 1998'de 5, 1999 yılında ise toplam 3 adet yüksek lisans ve/veya doktora tezi görülmüştür.

Türkiye'de 1990'lı yıllar önceki on yıllara nazaran her ne kadar Arap Edebiyatı üzerine yapılan çalışmaların arttığı bir zaman dilimi olsa da (Uzunoğlu, 2015, s. 4) hazırlanan eser sayılarına baktığımızda bu yükselişin çok büyük olmadığı görülebilir. Tam bu noktada bahsetmemiz gereken bir hususun da ülkemizdeki siyasi yönelimlerin hem Arap Dili ve Belagatı Ana Bilim Dalını içinde barındıran İlahiyat Fakültelerini hem de diğer fakültelerde bulunan Arapça merkezli bölümleri menfi veya müspet yönde etkilemesinin olduğu söylenebilir.

Nitekim artması gerekirken 2000'li yıllarda sayısal açıdan durağanlaşan lisansüstü çalışmaların sayısı yeni açılan İlahiyat Fakülteleri ve Şarkiyat bölümleri ile birlikte 2010'lu yılların başından itibaren tekrar olumlu yönde değişim göstermiştir. 2011 yılı savunulan toplam 6 adet tez ile daha önceki yıllara nazaran Türkiye'de en çok lisansüstü çalışmanın hazırlandığ 1 yıl olmuştur. Bu yılı takip eden yıllar ve üretilen tez sayıları şu şekildedir: $2012-3,2013-10,2014-16$, 2015 - 12, 2016 - 13, 2017 - 15, 2018 yılında ise üzerinde araştırma yaptığımız alan ile ilgili toplam 17 adet lisansüstü çalışma tespit edilmiştir. Yıllar ve hazırlanan tez sayılarına baktığımızda bir disipline hak ettiği değer verildiği takdirde oluşan somut değişimi gösterir niteliktedir.

Türkiye'de Modern Arap Edebiyatına dair tezlerin hazırlandığı üniversitelere baktığımızda edebiyat fakültelerine bağlı Arap Dili ve Edebiyatı bölümlerinde gözle görülür bir şekilde daha fazla eser verildiği tespit edilmiştir. Bu doğrultuda yıllardır söz konusu bölümü bünyelerinde barındıran Atatürk, Ankara, İstanbul, Gazi ve Selçuk Üniversitelerinde çağdaş edebiyat içerikli çalışmalar daha fazla görülür. Kuruluş amacı itibarıyla dini ilimlere yönelik akademik çalışmalar üreten İlahiyat ve İslami İlimler Fakültelerinin Arap Dili ve Belagati Anabilim dallarında ise daha çok Klasik Arap Edebiyatı ile Arap Dili üzerine yapılan çalışmalar ağırlıklı yekûnu oluşturmuştur.

Modern Arap Edebiyatına dair hazırlanan tezlerin üniversitelere göre dağılımı şu şekildedir: Atatürk Üniversitesi 28, Ankara Üniversitesi 24, Selçuk Üniversitesi - Necmettin Erbakan Üniversitesi $24^{*}$, Uludağ Üniversitesi 18 , İstanbul Üniversitesi 16, Gazi Üniversitesi 10, Bingöl Üniversitesi 6, Marmara Üniversitesi 5, Süleyman Demirel Üniversitesi 5, Dicle Üniversitesi 5, Yüzüncü Y1l Üniversitesi 4, Sakarya Üniversitesi 2, Çukurova Üniversitesi 2, Orta Doğu Teknik Üniversitesi 1, Harran Üniversitesi 1, Erciyes Üniversitesi 1, Osmangazi Üniversitesi 1, Aksaray Üniversitesi 1, Cumhuriyet Üniversitesi 1, İzmir Kâtip Çelebi Üniversitesi 1.

Yukarıda her ne kadar Modern Arap Edebiyatına dair çalışmaların dair araştırmaların İlahiyat dışındaki fakültelerde yer alan Arap Dili ve Edebiyatı, Arapça Öğretmenliği, Arapça Mütercim - Tercümanlık gibi bölümlerden daha fazla neşrolunduğunu söylesek de Uludağ Üniversitesi İlahiyat Fakültesi toplamda 18 lisansüstü çalışma öne çıktığı görülmüştür. Alana dair makaleleri incelediğimiz bölümde belirttiğimiz üzere ilgili kuruma hizmet etmiş Arap Dili ve Belagatı öğretim üyeleri Prof. Dr. Erol Ayyıldız ve Prof. Dr. Mehmet Yalar'ın bu verilerdeki etkileri çok bariz olduğu görülmektedir.

\section{Sonuç}

Bu makalede karşımıza çıkan ilk bulgu Modern Arap Edebiyatına dair çeviri ve tercüme eserlerin daha çok 1980'li yıllardan itibaren görünmeye başladığı ve takip eden yıllarda bu alana ilginin giderek arttığı görülmüştür. $\mathrm{Bu}$ geç kalmışlık her ne kadar bir eksik olarak görülse de Cumhuriyetin kuruluşundan sonra yeni bir hüviyet kazanan şarkiyat bölümlerinden öncelikli olarak Klasik Arap Edebiyatı ve Arap Dili alanlarında edisyon kritik, tahkik, metin inceleme tipi çalışmaların üretilmesi doğaldır. Nitekim filoloji disiplinlerinin genel yapısı itibariyle gelişimin köklerden yukarı/genelden özele doğru gitmesi gerekmektedir.

Araştırmamızda bir tür olarak kitabın, makale ve tez türü çalışmalardan oran olarak fazla olduğu tespit edilmiştir. Bunun sebebinin ise inceleme-araştırma türündeki akademik kitaplardan ziyade çeviri kitapların büyük bir yekûnu oluşturduğu görülmüştür. Yukarıda işaret etmeye çalıştığımız üzere edebi türdeki çeviri eserlerin akademik üretimden bağımsız bir şekilde hareket ettiği tespit edilmiştir.

Ülkemizde Cumhuriyet'in kuruluşundan bugüne eğitim kurumlarının artışı akademik yayınlardaki artışa da sebep olmuş Modern Arap Edebiyatı alanında hemen hiçbir eserin yayımlanmadığı yıllardan 3 nolu grafikte görüldüğü üzere alan ile ilgili eserlerin sayısının kat kat arttığı sürece dönüşmüştür.

\footnotetext{
* 2011 y1lı itibariyle Selçuk Üniversitesinin ikiye bölünmesinin istatistiklere yanlış yansımaması adına bu kısımda değerlendirme Necmettin Erbakan Üniversitesi ile birlikte yapılmıştır.
} 
Özellikle 2000'lerin ikinci yarısından itibaren her geçen yıl artan sayıda İlahiyat / İslami İlimler Fakülteleri, Arapça Öğretmenliği, Arap Dili ve Edebiyatı ile Arapça Mütercim Tercümanlık gibi şarkiyat bölümlerinin açılmasının bir sonucu olarak bu alanda yapılan akademik çalışmalara doğrudan yansıdığı görülmüşsür.

Niceliksel artış bir tarafa ortaya konulan eserlerdeki niteliğin de artırılması noktasındaki hassasiyet Arap Dili, Edebiyatı ve Belagatına dair yapılan çalışmalarının her yönden gelişebilmesi için alanın mensuplarına önemli bir görev düştüğü muhakkaktır.

\section{Kaynakça}

Ceviz, N. (2002). Nüsha - Şarkiyat araştırmaları dergisi, Ekev., (VI) 11, 235-237.

Cibran, H. (1946). Hak erenler. (Ö. R Doğrul, Çev.) İstanbul: Ahmet Halit kitabevi.

Dağbaşı, G., (2017). Arapçadan Türkçeye yapılan şiir çevirilerinin dil, estetik ve üslup bakımından incelenmesi (Yayımlanmamış doktora tezi). Gazi üniversitesi eğitim bilimleri enstitüsü, Ankara.

Demirayak, K. \& Çöğenli, M. S. (2000). Arap edebiyatında kaynaklar. Erzurum: Atatürk üniversitesi fen- edebiyat fakültesi yayınlarl.

Demirayak, K. (2016). Arap İslam edebiyatı literatür bilgisi. İstanbul: Cantaş yayıncılık.

Eren, A. C. \& Açer, M. (2001). Atatürk Üniversitesi fen edebiyat fakültesi doğu dilleri ve edebiyatları bölümünde yapılan Arap dili ve edebiyatı ile ilgili çalışmalar dizini (1967-2001). Erzurum: Atatürk üniversitesi fen-edebiyat fakültesi yayınlart.

Göktaş B. (2011). 1990-2008 yılları arası Arapçadan Türkçeye yapılan edebî eser çevirileri üzerine bir inceleme (Yayımlanmamış yüksek lisans tezi). İstanbul üniversitesi sosyal bilimler enstitüsü, İstanbul.

Harmancı, A. (2015). Yazının yükü. İstanbul: İz yayıncılık.

Işık, R. (2016). Diyarbakır Ziya Gökalp yazma eser kütüphanesindeki sarfa dair yazma eserler bibliyografyası.
Selçuk üniversitesi edebiyat fakültesi dergisi, 35, 245258.

Kadir, A. \& Timuçin, A. (1974). Filistin şiiri. İstanbul: Hilal matbaas1.

Kanar, M. (2014). Ülkemizde şarkiyatçılığın özeleştirisi. Doğu esintileri, 1, 1-11.

Karabacak, E \& Tahaoğlu, T. Ö., (1993). Arap dili, edebiyatı, kültürü, sanatı ve tarihi üzerine yapılan bilimsel çalışmalar bibliyografyası I. İstanbul: Boğaziçi üniversitesi matbaası.

Öz, A. (2009). Türkçede Mısır öyküsü ve romanına kuş bak1ş1. Hece öykü, 31, 70-82.

Uzunoğlu, M. V. (2003). Türkiye'de Arap dili alanında yapilan yüksek lisans ve doktora tezleri (1956-2002). Nüsha, 8, 7-32.

Uzunoğlu, M. V. (2005). Türkiye'de Arap dili alanında yapilan yüksek lisans ve doktora tezleri- II (1956-2004). Nüsha, 17, 7-36.

Uzunoğlu, M. V. (2015). Türkiye'de Arap dili alanında yapilan yüksek lisans ve doktora tezleri -III (19562013). Nüsha, 40, 1-52.

Yazıcı, H. (2002). Şarkiyat mecmuası. Nüsha, 4, 7-16.

Yetiş, İ. (2008). Türkçede çağdaş Filistin öyküsü. Hece öykü, 25, 82-87.

Yıldız, Ş. (2015). "Katkat Yasemin" adlı şiir çevirisi üzerine bir eleştiri. Selçuk üniversitesi edebiyat fakültesi dergisi, 0 (23), 179-192.

Zeydan, C. (1944). Kureyş bakiresi, (S. M. Yurdatap, Çev.) İstanbul: Ahmet Saidoğlu Kitabevi.

\section{INTERNET KAYNAKLARI}

millikutuphane.gov.tr/

tez.yok.gov.tr/UlusalTezMerkezi/

isam.gov.tr

yok.gov.tr 


\section{Extended Abstract}

This work includes a general assessment of works related to Modern Arabic literature published between 1928 and 2018, when the letter revolution was held in Republican Turkey. Among the types included in the study, master's and doctoral theses, translation and books and articles, the other types were not included in this study. The articles in the study were determined by scanning thirty-six academic journals related to the field, and the theses were determined on ISAM and YÖK websites.

As a result, in Modern Arabic Literature at nearly a hundred years Turkey which works and authors that more work, which names to greater focus and technique should be both thematic sense, guiding nature is considered to be the researchers who want to work in this field with the space to be determined.

The period we are in is an age in which the developing technological opportunities are reflected in the number of scientific studies and thousands of academic studies are published every day. In such a period of time, it becomes difficult to follow up the work done even in a single discipline. This situation increases the need for literature / bibliography type works on different scientific fields. In addition, the fact that "Arabic is a rich cultural language used in a wide geography unlike many languages" attaches a special importance to such studies in the field of Arabic Language and Literature.

Studies such as literature reviews, bibliography, indexes, as well as social sciences, are leading today, as in the past. Just as an explorer needed a map when she wanted to reach a place in ancient times, such literature studies also help the scholars to move forward in the field in question.

Another aim is to refer to the virgin periods, new names and different works of Modern Arabic Literature by pointing to the authors and copyrights that are repeated too much in this area where more and more works are seen every day.

This study of Arabic Language and Literature in Turkey, Arabic Teaching of Arabic Language and Rhetoric, interpreters the Interpretation such as sections and by Departments produced to be relevant as well as areas of academic works recording made in other parts of the study were also included. It is a study that examines the articles, books and the studies prepared at the graduate - doctorate level in terms of quantitative and partially qualitatively in terms of evaluating the data. It is a cross- sectional study since it covers a certain time period between 1928-2018. The types and numbers of the artifacts obtained in the study were examined with the help of statistics and graphics, and the changes in the historical course were examined in places in terms of qualitative aspects. In this study, which was prepared in the scale of the article, all of the data could not be shown as graphics and tables due to the limited space, however, the numerical data in question was tried to be given in the text as much as possible.

The first finding that we come across in this article is that translation and translated works on Modern Arabic Literature started to appear mostly from the 1980s and the interest in this field gradually increased in the following years. Although this belatedness is seen as a deficiency, it is natural to produce editorial-critical, investigative and text-review-type works, primarily in the fields of Classical Arabic Literature and Arabic Language, among the Oriental departments that have gained a new identity after the establishment of the Republic. As a matter of fact, due to the general structure of philology disciplines, development should go from the roots up / from the general to the specific.

In our research, it was determined that the book as a genre is higher than the article and thesis type studies. The reason for this was seen to be a large number of translated books rather than academic books in the study-research type. As we tried to point out above, it has been determined that literary translation works act independently from academic production.

Since the foundation of the Republic in our country, the increase in educational institutions has also led to an increase in academic publications. From the years when almost no works were published in the field of Modern Arabic Literature, as seen in the graphic no.

Especially since the second half of the 2000s, it has been observed that an increasing number of faculties of Theology / Islamic Sciences, Arabic Teaching, Arabic Language and Literature and Arabic Translation and Interpretation departments have been opened as a result of the academic studies in this field.

It is certain that the members of the field have an important duty in order for their works on Arabic Language, Literature and Rhetoric to develop in all aspects, apart from the numerical increase as well as the sensitivity to increase the quality of the works. 